\title{
Public health crises compounded: A high school equivalency context in the time of a pandemic
}

\author{
Isaiah Zukowski $^{1}$ ID $\cdot$ Zachary Parker $^{2} \cdot$ Daisy Shetterly $^{3} \cdot$ Kimberly Valle $^{4}$
}

Accepted: 19 February 2021 / Published online: 27 April 2021

(c) UNESCO Institute for Lifelong Learning and Springer Nature B.V. 2021

\begin{abstract}
High school equivalency (HSE) is a recognised alternative to a high school diploma in the United States. It offers an opportunity to a range of disadvantaged adult learners such as school dropouts, refugees etc. to attain an educational certificate enabling them to move on in their life. This article presents an autoethnographic case study of a non-profit HSE programme in Philadelphia during the COVID-19 pandemic. The four authors of this article, all of them instructors on the front line of the youth crisis in adult education, explore the broader context of non-governmental organisation (NGO) management and privatised HSE exams. In their research and their reflections, they found that the pandemic exacerbated existing economic and social inequalities, with both pre-pandemic and current delivery of their HSE programme failing to address the survival needs of a population which has long been living in crisis. Juxtaposing relevant youth-in-crisis literature with narratives both from before the pandemic and whilst living through it, the authors of this article discuss the funding and institutional constraints around the environment in which they teach. Their case study sheds light on competing priorities within the non-profit education landscape, highlighting both pitfalls and successes in HSE curriculum and administration. The authors conclude that rapid adaptation to online teaching tools, platforms and products is not the panacea that many outcomes generators would like it to be.
\end{abstract}

Keywords adult education · youth in crisis · high school equivalency · COVID-19 . online education · autoethnography

\section{Résumé}

Des crises de santé publique aggravées : l'équivalence des études secondaires en période de pandémie - Aux États-Unis, l'équivalence des études secondaires (High school equivalency/HSE) est une alternative reconnue au diplôme de fin d'études secondaires. Elle permet à des apprenants adultes défavorisés, par exemple à des décro-

Isaiah Zukowski

isz5006@psu.edu

Extended author information available on the last page of the article 
cheurs scolaires, des réfugiés, etc. d'obtenir un diplôme grâce auquel ils pourront progresser dans la vie. Cet article présente une étude de cas autoethnographique portant sur un programme à but non lucratif d'équivalence des études secondaires, mené à Philadelphie pendant la pandémie de COVID-19. Les quatre auteurs de l'article, tous enseignants en première ligne de la crise de la jeunesse dans l'éducation des adultes, se penchent sur la situation plus générale de la gestion, par des organisations non gouvernementales (ONG), des programmes d'équivalence des études secondaires et de la privatisation des examens dans ce cadre. Au fil de leurs recherches et réflexions, ils ont découvert que la pandémie exacerbait les inégalités économiques et sociales existantes, leur programme d'équivalences des études secondaires n'ayant pas réussi, tant avant que pendant la pandémie, à prendre en compte les besoins pour survivre d'une population frappée depuis longtemps par la crise. Les auteurs ont juxtaposé des documents avec des récits sur la jeunesse en crise, datant d'avant et de pendant la pandémie, pour aborder la question des contraintes financières et institutionnelles que subit l'environnement dans lequel ils enseignent. Leur étude de cas dévoile des priorités concurrentes au sein du secteur de l'éducation à but non lucratif, mettant en évidence les écueils et les réussites du curriculum d'équivalence des études secondaires et de la gestion de cette dernière. Ils concluent que l'adaptation rapide à des outils, plateformes et produits d'enseignement en ligne n'est pas la panacée que nombre d'obsédés des résultats aimeraient voir en elle.

\section{Introduction}

High school equivalency (HSE) is a recognised alternative to a high school diploma in the United States (US). It offers an opportunity to a range of disadvantaged adult learners such as school dropouts, refugees etc. to attain an educational certificate enabling them to move on in their life. This article presents a case study of a local non-profit HSE programme both before and during the COVID-19 pandemic. We tell the story from our perspective as instructors, investigating past challenges and successes, outlining how our own approach to teaching changed as a result of going online with youth in crisis. As teachers on the front line facing challenges amplified by the pandemic, we call renewed attention to the "youth crisis" in adult education (Carpenter et al. 2016; Carpenter and Mojab 2017), arguing that the global COVID19 crisis only exacerbates inequalities which already existed before the outbreak of the pandemic.

[Y]outh and young adults ... are fighting, migrating, protesting, labouring, commuting and hustling the world over just to survive and imagine some sort of future ... The social conditions in which youth come "of age" in today's world necessitate a broader engagement with their reality (Carpenter et al. 2016, p. 119). 
Exploring the political economy of the General Educational Development (GED) ${ }^{1}$ exam both as a multinational service and a contested regulatory apparatus (Tuck 2012), we focus on a particular educational context within non-governmental organisation (NGO) management and restructuring (Choudry and Shragge 2011).

In our experience, rapid adaptation to online teaching tools, platforms and products has undermined teacher-student communication and failed to address digital access divides rooted in long-standing disparities (Masucci et al. 2020). Now, as before, Congreso de Latinos Unidos, the NGO we work for, responds to public-private funding requirements, but rarely to community interest. The most recent crisis added by the pandemic presents only further destabilisation of the economy and a new set of risks for educational and social life.

We harbour deep concerns about the long-term viability of virtual education with vulnerable young people in North Philadelphia. While business and social services remain in lockdown, unemployment is at a record high. Citywide rebellions respond to anti-Black state violence, as stores shutter their windows to protect them from damage during daily protests. Many who depend on city services continue to struggle. ${ }^{2}$ All of these problems disproportionately impact young people of colour.

This article is guided by the question:

What is the impact of a novel pandemic on adult education, a sector already plagued by so many pre-existing social conditions?

We were already vulnerable workers at a large NGO before the pandemic hit, serving people who had long lived in crisis. In this article, we work through our reflections in order to ground ourselves and to plan steps forward.

First, we establish a layered accounts approach to autoethnography (Ellis et al. 2010). We then explore relevant literature on "youth in crisis" in adult education and "school pushout" (practices prompting school dropout), while examining the neoliberal context of HSE in Philadelphia. Through vignettes (brief evocative accounts), reflection and introspection, we weave a narrative of our own experience before and during the pandemic. As insiders, we "invoke" our readers to enter into the "emergent experience" (Ronai 1992, p. 123) of the research process. We reveal nested, mutually exacerbating tensions that operate at individual, programmatic and institutional scales. We conclude with a summary of challenges and post-pandemic opportunities for future research and potential policy.

\footnotetext{
${ }^{1}$ The General Educational Development (GED) exam refers to a series of tests for students who have not graduated from high school. The GED exam is recognised in the US (and many other countries) and indicates a high school level of education. For more information, visit https://ged.com/blog/what-is-aged/?lang=en [accessed 1 February 2021].

${ }^{2}$ This article was first drafted in June 2020.
} 


\section{Autoethnographic methods}

While layered accounts allow authors to frame existing research as sources of "questions and comparisons" to our experience (Charmaz 1983, p. 117; Ellis et al. 2010), our shared autoethnographic approach (Bratman et al. 2016) captures the individual perspectives of four teachers of each GED subject: Social Studies, Maths, Science, and Reasoning through Language Arts (RLA) respectively. Analysing educator experience at an NGO in Philadelphia before and during the pandemic, this methodology foregrounds the researchers as participants. Autobiographical narrative mixes with social, governmental and economic analysis, situated in a local and specific educational context (Ellis and Bochner 2000).

With a bureaucracy above us and a community around us, political autoethnography allows us to observe our own complicity. We do not "hide" from our own experiences or "keep them at a distance" (Taber 2010, p. 8). Rather, we use them as an entry point into "ruling relations" (ibid., p. 10) - in our case, the policy, funding and ideological landscape of HSE in Philadelphia. While our study reveals the importance of community autonomy, we opted to avoid subjecting our students to the "gaze of the academy" (Carpenter 2011, p. 108). Like participatory action research (PAR), autoethnography can challenge the researcher-researched dichotomy (Jordan and Kapoor 2016). Instead of feigning impartiality or scientism using words like "data, or abduction, or objectivity" (Denzin 2003, p. 270), our goal here is to tell our story as individual actors with unique personal interests and perspectives. We take Norman Denzin's position that

Ethnography is not an innocent practice. Our research practices are performative, pedagogical, and political. Through our writing and our talk, we enact the worlds we study. These performances are messy and pedagogical. They instruct our readers about this world and how we see it. The pedagogical is always moral and political; by enacting a way of seeing and being, it challenges, contests, or endorses the official, hegemonic ways of seeing and representing the other (ibid., p. 422).

Using our autoethnographic approach to illustrate our point, we criticise systemic mismanagement in the response to the ongoing public health crises, ${ }^{3}$ which existed long before the pandemic and have been exacerbated by it. We address narrow measurements of limited outcomes, which determine how knowledge workers negotiate scarce resources on behalf of racialised communities. Political autoethnography redirects disciplinary evaluation outward and upward. Our method functions pedagogically: for us, and for our administrators. In this way, we present a reflection on both our workplace and our work. Acknowledging our social distance and inspired by "youth resistance" (Tuck and Yang 2011), we present our own voices here as teacher resistance.

\footnotetext{
${ }^{3}$ We use the plural here to refer to the potential health consequences of participating in public school systems and of not completing high school (Freudenberg and Ruglis 2007; Ruglis 2011).
} 


\section{Methodology}

Our research team consisted of four teachers (the four authors of this article) teaching disadvantaged young adults (aged 17-24) in a non-profit HSE programme in Philadelphia in the United States. This programme was originally launched in 2005, one of us has been involved in it since 2015, and the other three successively joined later. As mentioned earlier, between us, we were teaching four subjects: Social Studies, Maths, Science, and Reasoning through Language Arts (RLA).

In accordance with the layered accounts approach, we performed data collection and analysis simultaneously (Ellis et al. 2010). The four of us began by narrating our experiences as instructors, including our education/work backgrounds and our arrival on this programme. We shared our narratives on GoogleDocs and talked through our reactions on video via Zoom. We documented both our experiences as NGO workers and our classroom management as HSE instructors, considering the programme as it existed pre-crisis and continuing chronologically through our arrivals. Taking into account our subject-specific observations and our professional development over the course of the programme, we then reflected on recent challenges during the pandemic. Isaiah and Zack identified themes that reverberated like echoes throughout our reflections. Understanding the everyday difficulties proved as crucial as uncovering the underlying obstacles presented by the pandemic. Importantly, relevant literature served as a source for our own reflection rather than an "objective measure of truth" (Charmaz 1983, p. 117). Structural vignettes juxtapose our voices and experience in our capacity as practitioners with analysis of critical scholarship. Before turning exclusively to autoethnographic narratives, the next sections introduce the research context of youth in crisis and set the scene of where we work.

\section{Youth in crisis, neoliberalism and NGOs}

\section{Youth in crisis}

State-wide lockdowns have been a reasonably effective last resort to mitigate the spread of the new coronavirus (Islam et al. 2020). These measures have also, however, exacerbated the existing racial and economic inequalities inherent to neoliberal governance. The ongoing public health crisis among the young - the increasing precarity that young people face - is a COVID comorbidity (Freudenberg and Ruglis 2007; Ruglis 2011). Entrenched political and organisational dysfunctions respond to and perpetuate this crisis. To understand these conditions, we enter into conversation with recent literature on youth in crisis in the field of adult education. We bring together our range of perspectives to identify obstacles that inhibit youth potential.

First, what does it mean to be young, or to be a youth? Though youth in crisis rarely gets mentioned in the field of adult education, the blurriness of youth as a category has been increasingly called to attention (Carpenter et al. 2016; Carpenter and Mojab 2017). Some adult education scholars urge us to consider that uncertain stage between childhood and adulthood as a time when people assert autonomy over their 
personal and social lives (UNESCO 2004, p. 4; Buchert 2014). In the field of youth studies, Mayssoun Sukarieh and Stuart Tannock (2016) invite us to think through how

young people and youth (whether as an ideology, identity, political actor and/ or social category) play a role in shaping, organising or legitimating social, cultural, political and economic structures and practices generally and globally (Sukarieh and Tannock 2016, p. 1285).

Since the financial crisis of 2008, the boundaries of youth had already faded, and the present economic disaster caused by the COVID-19 pandemic is now exacerbating this in the same dire conditions created by neoliberalism.

\section{Neoliberalism}

We understand neoliberalism to be a set of policy practices as well as an ideology. As David Harvey (Harvey 2011; Risager 2016) emphasises, neoliberalism can be understood as a deliberate class project to suppress organised labour. Its practices, which emerged in the 1970s, seek to privatise government services and deregulate corporate actors. State expenditure on healthcare, childcare, housing, food, transportation and education erodes in favour of investment in workforce development and self-help programmes. Laissez-faire competition in volatile markets produces few winners and many losers. With less government intervention and fewer protections, capital gains rarely trickle down to benefit the low-wage worker. An ideological emphasis on individual autonomy is both a cause and an effect of ongoing regulatory crises, which have cascading effects on social alienation (Wacquant 2009). Under the auspices of freedom and choice, working-class people are systematically provided fewer options (Brookfield and Holst 2011). As a result, young people face unprecedented unemployment rates and little government support at a time when people aged 15-24 comprise one in six of the world's population. The age range of youth in crisis could plausibly extend up to 30 or 35 , a demographic "uniquely positioned within the cultural, economic, and policy landscapes of political, material, and social insecurity" (Carpenter and Mojab 2017, p. 1).

According to this broad definition of youth, which is necessitated by so much insecurity, three of the teachers on our author team themselves fall into the category. But the problems we face differ greatly from those of our students. We live experiences cut along lines of class and race. To hold the differences, to nurture meaningful growth, our teaching method responds to programme "group dynamics" that are "shaped by socio-cultural, economic and historical factors rooted in local community contexts" (Prins 2009, p. 91). The non-profit HSE programme provides a space for different backgrounds as well as shared experiences. Daisy, Isaiah and Zack are white and grew up in cities and suburbs in the north-eastern part of the United States. Kim is a first-generation Mexican-American originally from El Paso, Texas. Our students' case managers, their job readiness coach, and our own 
immediate supervisor are Latinx adults from the area. Our at-will ${ }^{4}$ teaching and job positions frequently face potential funding cuts, but many staff (with a few notable exceptions) grew up outside of the environment of deprivation which characterises the area of North Philadelphia where we work. We recognise that our students rarely experience or pursue "leisure and unconstrained consumption", that privileged vantage "that normalizes white middle-class family formations and occludes the economic and social struggles of working-class and racialized people" (Ritchie 2017, p. 13). Privatisation forces Black and brown young people ghettoised by deindustrialisation either to seek client-based non-profit services or to enter the maws of the criminal justice complex: a "workfare" and "prisonfare" symbiosis (Wacquant 2009). We as NGO workers therefore both uphold and undermine normative middleclass expectations of work and education and the neoliberal discourses underpinning them, which are mandated by funding, albeit mitigated by our personal beliefs.

Our students are predominantly Puerto Rican low-income high school dropouts aged 17 to 24 . Their categorisation as "youth" functions as both a threat and a resource, emphasising their lack of "employable skills" as a risk of criminality, even while cash-strapped city systems strip them of "access to socialized services" (Ritchie 2017, p. 15). In Philadelphia, austerity lowers budget expenses by cutting programmes entirely or narrowing eligibility standards around education, income level, household size and carceral status. Over a quarter of the city's residents live below the poverty line, a multifactorial disparity related to and perpetuated by lack of educational access and unemployment. In 2016, the graduation rate of poor students from Philadelphia public schools was 61 per cent. In 2018, the same percentage of poor adults of working age were unemployed (Pew Research Center 2018). The jobs available to this vulnerable pool of labour without high school diplomas are scarce, low-paying and often under the table (off the record), compounding the effects of racialised state violence in housing, healthcare and the juvenile justice system. This cognitive dissonance of youth as both threat and resource can be seen in media coverage which misrepresents ongoing Black Lives Matter (BLM) protests. News outlets have argued that "Philadelphians between the ages of 18 and 24 who weren't associated with the protests" were largely responsible for crimes committed and were arrested for "looting and vandalism" (Vargas 2020). "Youth" is portrayed as a perpetrator of property destruction, ignoring the wider "economic and social struggles of working-class and racialized people" which lead to that state of affairs, namely few work credentials and even fewer options to receive help (Ritchie 2017, p. 13).

\footnotetext{
${ }^{4}$ In American labour law, at-will employment means that an employer can terminate an employee's contract at any time for any reason. In the absence of protections provided by union and public-sector employment, the legality of an at-will policy varies state by state, as do common-law exceptions for wrongful termination (Muhl 2001). From our understanding as workers, Pennsylvania is conservative on these exceptions and generally favours employers in contract termination disputes.
} 


\section{NGOs}

A pernicious mechanism of neoliberal policy and ideology is therefore to alienate, criminalise and penalise youth as individual actors while systematically undermining individual agency. Savannah Shange (2019) calls this a "carceral logic": a tendency to isolate social problems into isolated instances of right and wrong, to avoid structural considerations in favour of technical value judgements (Gilmore 2007). This logic of growth links "prisonfare" to "workfare" (Wacquant 2009), mirroring what we observe when NGOs opt for band-aid solutions that benefit corporate or funder interest. Aziz Choudry and Eric Shragge (2011) identified "NGOization": how mission-driven organisations focus on specific, technical cases at the expense of capitalism-critical advocacy (Carpenter 2015; Choudry 2010). Individuals in crisis are policed, counselled and reformed to feed funder-set evaluation metrics and further privatise public benefits (Kamat 2004).

This reproductive practice never fully addresses the underlying causes of the oppression. The state, working through NGOs, "intervenes but does not provide" (Choudry and Shragge 2011, p. 504). As a result, isolated cases never cease; in fact, they often worsen. Rather than organising active participants in social struggle over the role of government, NGOs create additional services for clients to meet additional needs. Credentialled experts present off-the-peg solutions to people locked out of access to their own decision-making. NGO administrators may be more interested in retaining their powerful positions than in achieving meaningful outcomes, a tendency aptly described as "managerial feudalism" (Graeber 2019). Seen in this light, the sprawling workfare apparatus appears to function more as a state-subsidised jobs programme for the educated and middle class, and a vehicle for corporate profit, than as a pathway out of intergenerational poverty.

Our theory and practice are caught between the domains of youth in crisis, adult (youth) education, neoliberal policy and ideology, and NGOisation. Straddling these different areas, we see HSE as a potential site of "youth resistance" as much as a place to learn employable skills (Tuck and Yang 2011). The rate at which young people drop out of ill-equipped and inadequately supported high schools, facing a future of lowwage employment or criminalisation, constitutes a "public health crisis" in US cities (Freudenberg and Ruglis 2007). The GED exam presents a limited choice for youth seeking economic and social security in Philadelphia and other US cities (Rachal and Bingam 2004; Ruglis 2011). Despite the "uneven outcomes" offered by the GED exam, more have sought this "depleted credential" in the face of widespread lack of work (Tuck 2012, p. 2), since, increasingly, the only alternative is criminalisation (Gilmore 2007; Wacquant 2009). Meanwhile, our abilities to intervene as direct-service workers are limited by the privatised regulatory and funding landscape.

\section{Changing tests and changing markets}

The General Educational Development (GED) exam's evolution maps onto broader shifts in United States neoliberal political economy (Tuck 2012). The GED exam was launched in 1942 as a government programme through the American Council on 
Education (ACE). Its purpose at its inception was to reintegrate returning World War II veterans into higher education and the workforce. In the 1970 s, the minimum age was lowered in order to make the test accessible to high school dropouts. By the early 2000s, the GED exam had "adolescentized", placing pressure on programmes like ours to make up for high school and/or youth in crisis (Rachal and Bingham 2004). Eve Tuck's study of youth and the GED exam in New York found that students often "felt unwelcome" in their old high schools, facing issues such as

disrespectful treatment from teachers and other school personnel, violence among students, arbitrary school rules, and the institutional pressure of high-stakes testing (Tuck 2011, p. 818).

We have heard similar reports from students in Philadelphia. We see the regulatory and funding landscapes for HSE growing more privatised, convoluted and austere since Tuck's research, especially with the emergence of two new HSE credentials and a revamped private GED exam (Davidson 2017; Zinth 2015).

Pearson LLC, the world's largest for-profit education company, leveraged its industry power with ACE in 2011 to form a joint venture in the GED Testing Service (Simon 2015). Working with management consultants, the GED exam was modified under the rubric of developing new standards for mathematics and literacy and creating workforce development mandates to comply with the Obama Administration's federal Common Core. The new version of the test eliminated fictional literature in favour of non-fiction, while in maths, analytical reasoning was emphasised over formulaic memorisation (Simon 2013). The new test was taken entirely online, with a paper option available only in exceptional circumstances. The cost of testing doubled to USD 120 (though states subsidise this cost to varying degrees).

While these moves were not explicitly profit-seeking, they had the effect of generating more retakes, which increased price and lowered service costs. These changes correlated with an almost 56 per cent decrease in test-takers and a 35 per cent reduction in pass rates between 2013 and 2014 (Mulhere 2015). In response, the GED Testing Service changed the pass mark from 150 to 145 credit points, effective from the start of 2016 (Davidson 2017).

Through these adjustments, competitors saw an opportunity for market entry. In a bid to challenge the GED Testing Service's state monopoly, the non-profit Education Testing Service partnered with the Iowa Testing Service to develop a lower-cost alternative more in line with the standards of the previous GED exam: the High School Equivalency Test (HiSET). At the same time, CTB/McGraw-Hill also developed its own version, the Test Assessing Secondary Completion (TASC). At present, the HiSET is offered in 23 states and the US territories, the TASC is available in 14 states, and 11 states have elected to no longer offer the GED exam. Within this competitive milieu, young people in crisis have more options than ever. 


\section{Our NGO and the ties that bind}

In Philadelphia, the private testing landscape works with a complex apparatus of government and non-profit actors in order to administer HSE. Federal Temporary Assistance for Needy Families (TANF) money mixes with funds from non-profit and corporate donors and the city's Department of Health Services and the Workforce Development Board (PYN 2020). Our NGO presents a microcosm of this broader network.

Congreso de Latinos Unidos (henceforth referred to as Congreso) describes itself as a multiservice agency championing "economic self-sufficiency" and "well-being" for North Philadelphia's Latino community (Congreso 2020a). Developed decades ago from an advocacy organisation, Congreso has since become primarily a subcontractor for education, employment, health and social services. Its "Mission 2 Impact (M2I)" initiative emphasises a "womb-to-work" strategy, intervening with services for people at every stage in their lives (Congreso 2020a). Three divisions - health and wellness promotion, housing navigation services, and workforce development - all strive to achieve long-term outcomes rather than short-term interventions.

As a component of the Education and Workforce Services division, our HSE programme is branded as "E3" - Education, Employment, and Empowerment - through a grant contract from the Philadelphia Youth Network (PYN). Since its establishment over a decade ago, the funding initiative has sponsored at least four different sites across the city: ours in the North and others in West, Center and South locations (Murphy 2017). The E3 programme strongly promotes its adaptability to the individual needs of youth learners. HSE is offered by instructors and supported by social workers, alongside internship programmes and workforce development training. PYN and Congreso nominally coordinate evaluation of our E3 programme site using a variety of overlapping trademarked approaches, from the Weikart Center for Youth Program Quality (CYPQ 2013) to Congreso's Primary Client Model ${ }^{\mathrm{TM}}$ and Mission 2 Impact (Congreso 2020a, 2020b). Like all good ideas, these models, brands and discourses can succeed or fail depending on how they are implemented.

In our view, Congreso is on a long-term administrative mission to assess whether services are integrated or effective, and it struggles with direct-service practitioners and community members to appropriately define and capture outcomes. Despite its grassroots origins, the organisation now reproduces the "carceral logic" (Shange 2019) of the institutional landscape: an emphasis on professionalised crisis intervention over long-term political change (Choudry and Shragge 2011; Gilmore 2007; Wacquant 2009). Bureaucratic norms, hierarchies and procedures serve to regulate an overwhelming sense of job insecurity. Open communication and coordination between funds allocators, direct-service workers and clients from the neighbourhood is strongly discouraged. Direct-service workers take responsibility for the success and failure of clients, but they are not seen as sufficiently credentialled to engage with policy. Instead, consultant experts in programme design are handsomely paid to interpret data in collaboration with 
administrators. When our NGO touts "client-centred, data-driven approaches", it means that they use clients (and workers) as data (Congreso 2020b). Administrators insist that NGO operations remain above our paygrade, beyond our expertise, and outside of our control.

\section{Pre-COVID teacher resistance}

In spite of challenging workplace and community contexts, past work on "youth resistance" in New York has seen the GED exam as a getaway from the structurally racist violence of city secondary education (Tuck and Yang 2011; Tuck 2012). Our programme has similarly become a "counter-space" for students, providing space for voice and silence, for learning and mentoring separate from public institutions (Schwartz 2014). As in other Adult Basic Education (ABE) programmes, our space also "feels like a little family" (Prins et al. 2009). We help one another beyond the typical office norm, providing social support both inside and outside the HSE space. We use this community as a source of strength from which to advocate internally for our own self-interest. The following vignettes illustrate how narrowly defined funding outcomes constrain programme goal-setting, all the while reproducing cycles of teacher and student burnout. We then show how teachers have leveraged these contextual dysfunctions.

\section{Overworked and undermanaged}

Zack first entered our NGO in 2015 following a two-year residency on a doctoral programme in Educational Studies in Canada. There, he apprenticed in educational research and trained in high leverage, inclusive $\mathrm{K}-12$ maths and science teaching methods (Jao et al. 2018, 2020). Zack describes his entrance into the HSE programme as follows:

When I started I was unfamiliar with the GED exam. I soon discovered that youth HSE instruction presents unique challenges. I tried to incorporate what I had learned in Canada, but with limited success. My ability to teach effectively was limited by many factors. Narrow funder-mandated outcomes regarding the number of GED tests passed forced me to focus on efficiency over intentionality. I lacked time and support for lesson planning and professional development. I taught all four subjects (Math, Science, Social Studies, and RLA), in two of which I had no training. The crowded classes had students with wide-ranging educational backgrounds and commitment levels. Many students were "pushed out" from the public school environment (Tuck 2012) due to unhealthy conditions, often from high grade levels, which is a public health crisis in itself (Ruglis 2011).

I decided to simplify the subject matter and split the class into two topics: reading comprehension of current events (and SS/RLA/Science GED questions) and the GED math curriculum. Students generally resisted the cogni- 
tive demand of high-leverage teaching practices, especially with mathematics. They favoured "step-by-step" instruction and "packets" with "what's on the test". I met them halfway. We co-constructed "step-by-step" instructions together as we learned, and I made sure the students had packets including practice GED problems. After only five months, I became the veteran GED Instructor. Staff turnover is consistently a problem. (Zack)

HSE education required Zack to adapt quickly to the needs of funders and students, often without prior knowledge from formal study. Overworked and soon the only instructor left, he sought more time for curricular development, building a schedule that could support both quality instruction and the needs of educators.

At the same time, Pennsylvania began offering the HiSET. Unfortunately, teachers did not have sufficient time or resources to implement it. Since the GED exam had lowered its pass mark in January 2016 from 150 to 145 credit points (Davidson 2017), some students retroactively passed previous subject tests. Moreover, all students were already working towards the GED exam when the HiSET was introduced. For these reasons, educators opted to keep the programme GEDspecific, with teachers focusing on two subjects each. This structure remained in place until the arrival of Daisy in 2018.

Daisy describes how the programme worked two years later and the roles she was expected to fulfil as follows:

I began at the programme as a Social Studies and Language Arts GED teacher. At the time, there were two other teachers on the programme: a low literacy and numeracy instructor, and another full-time GED teacher who taught Math and Science. I focused on understanding student learning needs and adapting my previous GED teaching experience. My goal was to establish a trauma-informed learning environment with individualised levels of academic support. I hoped to meet the range of learning levels within each class. (Daisy)

Teachers are expected to play administrative, educational and social support roles, under supervision that is at once hands-on and hands-off. In this context, teachers make an "ethical commitment" to students "beyond the expectations the students have" (Bourassa and Margonis 2017, p. 623). In an adult education context, we strive to create a "place of refuge" where students are free to learn at their own pace and on their own terms (LaDousa and Baldridge 2017, p. 125). Students often remain engaged in our community after graduation.

To funders and supervisors, on the other hand, the raw number of HSE credentials is the only meaningful measure of teaching efficacy and student success. Daisy recounts her early experience with programme evaluation:

Early on, it became clear that management was largely unconcerned with the quality of the academic programme. While I had come into the job knowing that the turnover rate was high, I was disappointed by how little my boss seemed to care what was happening in the classroom. This changed in 2018, when GED attainment levels fell below previous annual bench- 
marks. Programme directors swooped in to restructure our programme without thoughtful engagement with staff, cramming more class time onto our already full schedules and mandating monthly intakes of new students. " $25 \%$ more class time will equal 25\% more GEDs" was an economistic rationale that we were given. To a certain extent, it was true. The more students to whom we opened up the programme, the greater the odds were of admitting students who were ready to pass the test. However, by overcommitting already strained teachers, the quality of the programme suffered. There simply was not enough time to devote to the sort of intensive planning that is so crucial in mixed-level classes. (Daisy)

Instructors laboured under time and supervision constraints, and frequently left due to stress. Programme evaluations assessing GEDs attained did not capture all those who were left behind. Esther Prins (2017) describes the phenomenon as "creaming" of outcomes, when a certain number of "bubble kids" are supported and held up at the expense of the many who are struggling. In our case, the outcome percentage of GEDs attained was inflated. Educators faced neoliberal "teacher pushout" alongside further youth pushout (Tuck 2012, p. 56). Students either remained stuck on the programme or dropped out while instructors did their rotations.

Using curricular shortcuts, some semesters we were able to get many of these "pushed out" students to pass the GED exam by their expected graduation dates. Still, we left many students behind. Even when we were able to exceed the funder mandate of "GEDs passed", far too many who were not "bubble kids" (Prins 2017) were left to continue to struggle. Frustrated by this, I quit the programme in 2016. Some of the same students were there when I returned in 2019. (Zack)

For years, the programme needed either more teachers or fewer students. After all, where else could these youth go? We did not seek to replicate high school and its dysfunction, but we were not adequately equipped to meet the wide range of incoming needs. We feared pushing out people who had already been "pushed out" - and we feared being pushed out ourselves.

We can relate to an ABE context in which a "director explained the work accomplished at the [GED programme] without regard for the insights of teachers and students" (LaDousa and Baldridge 2017, p. 117). Student agency is defined narrowly within the "domain of activity, employment, or better income" (ibid., p. 118). The mandated outcomes of our funding fail to capture the full scope of work between teachers and students.

\section{Advocacy and reform}

In 2019, following a year of strong outcome performance, Zack and Daisy were in a better position to advocate for themselves. They argued effectively, with strong support from a new supervisor, in favour of restructuring the programme to address general burnout. They geared the programme towards the students who needed the most support, getting "bubble kids" to graduate quickly. That summer, under 
a revised budget, they sought out an additional HSE Instructor and a low literacy instructor. The new instructors started less than a week before the new academic year (2019-2020). With new teacher capacity, the team began researching the HiSET in order to offer it alongside the GED exam.

Isaiah brought GED teaching experience gained at a Latinx community programme in Baltimore, MD, as well as a professional background in LGBT service provision. When he joined our HSE programme, he initially took on Social Studies and Science subjects. Kim had a journalism and education background from the Peace Corps. She began teaching lower literacy levels part-time. While we suddenly found ourselves with more curricular freedom than ever to develop subject-specific lessons, the broader culture of the organisation remained largely unchanged. Isaiah describes his frustration with competing organisational priorities as follows:

I came to work every day with expectations that immediately unravelled. Plans were cancelled, rescheduled and reordered by a decision-making system I did not understand. Higher managers focused largely on the expectations of programme evaluators. Students were treated as subjects of rehabilitation in order to distract from the areas most in need of reform. Students said what we could not: "What the fuck is this even for? This is fucking bullshit!", yelled one student after attending a mandatory event sponsored by a multinational bank, giving financial advice to people who do not have bank accounts. The event took up one third of the teaching time for that day.

Instead of having their time viewed as precious, students were treated as part and parcel of the problems the organisation is meant to fix. If they were caught wandering to the bathroom or to the kitchen to eat or speak with their friends, other staff would complain that they were not sufficiently disciplined. The local police precinct was invited to use the building as a break room, while students were not permitted to spend time outside the classroom. The police did not make the students feel safe. (Isaiah)

Limited time and supervision continued to be obstacles, compounded by the carceral logic of the NGO. Space is regulated by security at the front of a concrete building that would resemble a prison but for a colourful mural on its façade. Staff are encouraged to keep their personal belongings hidden away from clients due to the risk of theft. The movements and activities of students within the building are monitored by police officers. Meanwhile, staff are left with competing priorities: the efficiency emphasised by our employer, and our own critical orientation. Kim struggled with similarly competing priorities:

I felt unprepared at the outset, as the other instructors had more time to plan than I did. My former manager provided very limited resources, communication and training to help me get started. Navigating my way through the organisation's culture, I quickly felt the burnout among the other instructors and case managers.

Students and instructors often find themselves having to cancel prepared sessions due to poor communication on the part of other staff regarding use of 
teaching space. These frequent cancellations cause instability between teachers and students and reflect uncertainty on the part of the organisation. The organisation's values are to serve the community and provide a path for growth. Colleagues in the GED programme have requested expansion of spaces for students, but the facility still lacks adequate space to carry out educational programming and other projects. (Kim)

In response to supervision and space issues, we continued to exercise more control over the programme. Still, we could not change the space in which we operated. In 2020, we formally adopted the HiSET and dedicated one teacher to each subject. These challenges bolstered camaraderie. Fighting for staff autonomy and students' interests, the present staff of ten has come to feel like a family. We listen to the students and to each other. While our grievances were often overlooked, we continued to make additional changes in 2020. Zack switched to a part-time position teaching maths, and Kim to full-time work. Daisy shifted to teaching science. What seemed a simple switch for our programme became an enormous obstacle to manage. Just as we felt ourselves gaining some real traction, the pandemic hit.

A collective narrative emerges from these individual and chronological narratives. The institutional history of the programme is one of direct conflict between the entrenched expectations of long-term managers and administrators and the immediate needs identified by itinerant educators. Managers and administrators seek to boost GEDs produced in deference to outcome measurements, eager to game attendance metrics to reflect higher outcomes. These outcomes, however, overlook those students who are being left behind. All teachers indicated feeling a lack of sufficient professional support. In response, we fought for time, space, autonomy and retention.

\section{Teaching during the pandemic}

On 17 March 2020, Pennsylvania Governor Wolf's state-wide stay-at-home order went into full effect. ${ }^{5}$ Our NGO had notions of returning with cleaning regimens, but ultimately opted to follow the School District of Philadelphia's protocol and cancel all in-person services. Although instructors had just finished a cycle and anticipated two weeks for curriculum and professional development, we were mandated to move services online. This pushed instructors to shift quickly to a plan of action to "continue to best serve our students individually" (Kim). Reflecting on this time, teachers felt that the existing challenges were worsened by the pandemic. Rather than working in a cramped physical space, we now needed to create a shared online learning space, but we found ourselves facing the same old fundamental issues of inadequate preparation time and job funding instability.

\footnotetext{
5 The World Health Organization had upgraded the COVID-19 outbreak to pandemic status on 11 March 2020 (WHO 2020).
} 
Space had already been limited in overscheduled classrooms shared with other programmes housed in the building. The pandemic revealed just how necessary that limited space was. Some students had chosen our organisation specifically because virtual education did not work for them. The pandemic cast youth already living in crisis into further precarity. Those living in unsafe conditions due to domestic violence or housing insecurity were now forced to lock themselves inside in those environments. Ninety-six per cent of our students live in a zip code where over twenty per cent of the population tested positive for coronavirus.

Teachers found that any notion of normal HSE preparation had to be side-lined in favour of wellness check-ins and resource allocation. Teachers worked with case managers to provide food, resource referrals and computers. However, budget issues limited the number of students who could receive resources available. The technology gap widened for those who did not have Wi-Fi or a computer at home but still needed vital information about emergency resources and services (Pinder 2020). Because many advanced students (the "bubble kids") had already graduated, we were left working with students who "required high-intensity academic and emotional support" (Zack).

The individualised and group curriculum we had previously employed was "difficult to accommodate with online platforms" (Kim). In order to provide a semblance of curricular design, teachers opted for the online learning platform IXL because it was compatible with mobile smartphones and covered $\mathrm{K}-12$ critical competencies. Teachers struggled to encourage students to complete coursework or turn up to virtual meetings and follow-up sessions. To combat these time and motivation issues, instead of a class model where students can tutor and mentor each other, teachers developed an entirely 1:1 curriculum. "How those platforms are differentially accessible to students with learning disabilities needs to be better understood" (Daisy).

In June 2020, our programme also faced a grant renewal period. In every month of the pandemic, a different possibility for programme termination appeared.

The testing centre was promised to open, but then there were concerns about even that. Nothing happened. So students were left without an end game, without hope for completion. The city-wide graduation, too, was cancelled, (Isaiah)

Meanwhile, teachers were obliged to provide metrics and performance evaluation to advocate for our existence in two separate contracts, a July-October interim contract and a renewal contract for the next fiscal year. We were placed in the uncomfortable situation of having to advocate for our utility in a crisis while at the same time recognising the shortcomings of operating virtually due to COVID-19.

The city's fiscal response to the pandemic has tested the waters of further economic austerity (McCrystal et al. 2020). The Office of Adult Education was eliminated for months, along with an $\mathrm{ABE}$ referral programme and community computer lab, and was only reconstituted under a different name after a coordinated advocacy effort. PYN approved programme funds for Congreso's E3 contract periods, maintaining salaries while cutting funds that would go into students' pockets to meet survival and technology needs. While protests continue to rock Philadelphia, and with budget decisions still under way, the future of adult education and HSE resources remains in doubt. 
Ultimately, we fear that virtual learning will seem a more viable route to programme managers in the future due to its low cost and scalability. In October, PYN expanded the E3 network to include more site locations with fewer mandated student numbers. The size and age of our programme precluded us from joining in with this strategy, as our funder mandated increased enrolment quotas compared to the last fiscal year. Within our NGO, supervisors continue to tout our programme's COVID response, signalling further enthusiasm for additional off-site learning services, even while youth are pushed further into crisis. The pandemic presents new opportunities for private intermediaries, which we observe in the proliferation of video conferencing services, online learning platforms, and digital consultants. Teachers feel complicit in boosting the performance metrics of this programme, but see no alternative given the current job insecurity. Staff and students are holding on to the programme, knowing its potential for growth and resistance. We hold onto each other like family, even while the lockdown makes communication difficult and strips away space.

\section{Conclusion}

The HSE literature tells the story of ongoing public school failures which contribute to a growing population of youth in crisis. High schools continue to "push out" students (Tuck 2012). Mission-driven NGOs, government agencies and private profiteers treat this slow-burning public health crisis with "carceral logic" (Shange 2019), where "individual agency" is the "key path to social change" (Freudenberg and Ruglis 2007; Shange 2019, p. 19). In the post-2014 HSE testing landscape, the literature boasts of increasing "school choice" even while actual viable opportunities dwindle. We find that while HSE programmes continue to absorb the population of youth in crisis, programmes such as ours continue to end in student and teacher burnout.

Our NGO maintains an apolitical theory of change, continuing its attempts to secure funding, despite evidence that creating new client services or leadership initiatives will never be sufficient to effect social change (Choudry and Shragge 2011, p. 503). Though our programme has gone through many changes in the past several years, a viable long-term virtual programme remains out of the question. Such a programme may prove to be a useful supplement, if we maintain realistic expectations and a critical view of its limitations (Selwyn and Jandrić 2020). But gaps in access to the internet and computers make virtual education impossible if we cannot provide the equipment for free or at low cost (Masucci et al. 2020). In Philadelphia, the digital divide continues to widen (Pinder 2020).

Underneath the false discourse about choice and individual agency, the COVID19 pandemic compounds existing social inequalities (Nicola et al. 2020). Rates of traumatic stress, housing and food insecurity and domestic violence continue to increase (Horesh and Brown 2020). Black and brown communities face these issues disproportionately, along with higher rates of COVID-19 infection (Hlavinka 2020). Profit-seeking corporations and funds-strapped NGOs continue to siphon public dollars to internal operations. Students trapped in the "workfare" and "welfare" continuum are made to consume its values (Wacquant 2009). 
Still, suffering brings solidarity. During the course of this research over the past few months, we have joined many colleagues attempting to organise themselves in support of BLM and broader social justice. The group presented concrete action steps to upper management and the board of directors. We see this effort as a potential future locus of resistance. As this article calls for action for change, we continue to probe our social distance and organise further efforts.

\section{Epilogue: opportunities for research and social change}

Future research must continue to parse out the real beneficiaries and victims, the institutions and individuals, within the bloated workfare apparatus. For our part, we plan research that is worker-led as much as it is teacher-led, including the rest of our ten members of staff (past and present), our fellow case managers, job readiness coaches, and administrative workers. We must also find ways to centre student voices in the design, methods and dissemination of our research, through transgressive learning (Peters and Wals 2016), participatory action or PAR (Carpenter and Mojab 2017; Jordan and Kapoor 2016; Ruglis 2011; Tuck 2012). For the time being, rather than fetishising the local, we have chosen to present a systemic microcosm by way of autoethnography (Carpenter 2015). Discussing the contextual effects of neoliberal policy and ideology, our narrative chronicles young people's search for autonomy. Teachers struggle to improve our working environment, while students strive to improve their material conditions.

We criticise the accountability framework that prioritises workforce entry over racial and economic justice. Flexible federal funds, city governments and missiondriven foundations could better address school pushout and youth unemployment by focusing on communication and coordination pipelines between existing ABE networks across the city (Prins et al. 2018). This coordination should allow practitioners to share resources and to communicate with one another beyond the limits of scripted seminars.

When we had the space throughout this research process to talk freely about our work as HSE practitioners, we frequently returned to the greatest impediments to student success: childcare, housing, healthcare and food insecurity. The state must intervene directly to address these material needs, not outsource their provision. While ABE programmes continue to serve a quasi-governmental function, they must have the freedom to develop contextual outcomes, with fewer strings attached to material investment in communities. People from local neighbourhoods should be promoted within community-based organisations based on their connection to the community, their life experience, and their client approach. Our suspicions should be raised when mission-driven NGOs defer to credentialled expertise from outside, which too often serves only to fine-tune superficial metrics while structural inequality and the pandemic endure. Education alone cannot address all social ills.

Acknowledgements We would like to thank Dr Ying-Syuan Huang for helpful feedback and comments on an earlier draft of this article. 


\section{References}

Bourassa, G.N., \& Margonis, F. (2017). Monstrous generosity: Pedagogical affirmations of the "improper". Studies in Philosophy and Education, 36(6), 615-632. https://doi.org/10.1007/ s11217-017-9566-3.

Bratman, E., Brunette, K., Shelly, D.C., \& Nicholson, S. (2016). Justice is the goal: Divestment as climate change resistance. Journal of Environmental Studies and Sciences, 6(4), 677-690. https://doi. org/10.1007/s13412-016-0377-6.

Brookfield, S., \& Holst, J. (2011). Radicalizing learning: Adult education for a just world. San Francisco, CA: Jossey-Bass.

Buchert, L. (2014). Learning needs and life skills for youth: An introduction. International Review of Education, 60(2), 163-176. https://doi.org/10.1007/s11159-014-9431-3.

Carpenter, S. (2011). Theorizing praxis in citizenship learning: Civic engagement and the democratic management of inequality in AmeriCorps [doctoral thesis].Toronto, ON: University of Toronto. https://tspace.library.utoronto.ca/handle/1807/31706.

Carpenter, S. (2015). The "local" fetish as reproductive praxis in democratic learning. Discourse: Studies in the Cultural Politics of Education, 36(1), 133-143. https://doi.org/10.1080/01596306.2013. 871234.

Carpenter, S., McCready, L., \& Mojab, S. (2016). Youth, social crisis, \& learning. International Journal of Lifelong Education, 35(2), 119-121. https://doi.org/10.1080/02601370.2016.1164471.

Carpenter, S., \& Mojab, S. (2017). Youth as/in crisis. Rotterdam/Boston/Taipei: Sense Publishers.

Charmaz, K. (1983). The grounded theory method: An explication and interpretation. In R.M. Emerson (Ed.), Contemporary field research: A collection of readings (pp. 109-125). Prospect Heights, IL: Waveland.

Choudry, A. (2010) Global justice? Contesting NGOization: Knowledge politics and containment in antiglobalization networks. In A. Choudry \& D. Kapoor (Eds), Learning from the ground up: Global perspectives on social movements and knowledge production (pp. 17-34). New York: Palgrave MacMillan.

Choudry, A., \& Shragge, E. (2011). Disciplining dissent: NGOs and community organizations. Globalizations, 8(4), 503-517. https://doi.org/10.1080/14747731.2011.585855.

Congreso (2020a). Mission 2 impact [dedicated webpage]. Philadelphia, PA: Congreso de Latinos Unidos, Inc. Retrieved 10 November 2020 from https://www.congreso.net/impact/mission-2-impact-2.

Congreso (2020b). Primary client model [dedicated webpage]. Philadelphia, PA: Congreso de Latinos Unidos, Inc. Retrieved 10 November 2020 from https://www.congreso.net/impact/prima ry-client-model.

CYPQ (Center for Youth Program Quality) (2013). Approach [webpage]. Ypsilanti, MI: David P. Weikart Center for Youth Program Quality. Retrieved 10 October 2020 from http://cypq.org/about/approach

Davidson, J.C. (2017). National shifts in adult basic education: Workforce innovation and opportunity act, ability to benefit, and high school equivalency tests. New Directions for Community Colleges, 180, 27-35. https://doi.org/10.1002/cc.20278.

Denzin, N.K. (2003). Performing [auto] ethnography politically. The Review of Education, Pedagogy \& Cultural Studies, 25(3), 257-278. https://doi.org/10.1080/10714410390225894.

Denzin, N.K. (2006). Analytic autoethnography, or déjà vu all over again. Journal of Contemporary Ethnography, 35(4), 419-428. https://doi.org/10.1177/0891241606286985.

Ellis, C., \& Bochner, A.P. (2000). Autoethnography, personal narrative, reflexivity: Researcher as subject. In N.K. Denzin \& Y.S. Lincoln (Eds), Handbook of qualitative research (2nd edn, pp. 733-768). Thousand Oaks, CA: Sage Publications.

Ellis, C., Adams, T.E., \& Bochner, A.P. (2010). Autoethnography: An overview [40 paragraphs]. Forum Qualitative Sozialforschung/Forum: Qualitative Social Research, 12(1), Art. 10, http://nbn-resol ving.de/urn:nbn:de:0114-fqs1101108.

Freudenberg, N., \& Ruglis, J. (2007). Reframing school dropout as a public health issue. Preventing Chronic Disease, 4(4), 1-11. Retrieved 10 November 2020 from https:/www.cdc.gov/pcd/issues/ 2007/oct/07_0063.htm.

Graeber, D. (2019). Bullshit jobs: A theory. London: Penguin Books.

Gilmore, R.W. (2007). Golden gulag prisons, surplus, crisis, and opposition in globalizing California. Oakland, CA: University of California Press.

Harvey, D. (2011). A brief history of neoliberalism. Oxford: Oxford University Press. 
Hlavinka, E. (2020). COVID-19 Killing African Americans at shocking rates. MedPage Today, 1 May [online article]. Retrieved 10 November 2020 from https://www.medpagetoday.com/infectiousdisea se/covid19/86266.

Horesh, D., \& Brown, A.D. (2020). Traumatic stress in the age of COVID-19: A call to close critical gaps and adapt to new realities. Psychological Trauma: Theory, Research, Practice, and Policy, 12(4), 331-335. https://doi.org/10.1037/tra0000592

Islam, N., Sharp, S.J., Chowell G., Shabnam S., Kawachi, I., Massaro, J.M., D’Agostino, R.B., \& White, M. (2020). Physical distancing interventions and incidence of coronavirus disease 2019: Natural experiment in 149 countries. BMJ, 370, m2743. https://doi.org/10.1136/bmj.m2743

Jao, L., Wiseman, D., Kobiela, M., Gonsalves, A., \& Savard, A. (2018). Practice-based pedagogy in mathematics and science teaching methods: Challenges and adaptations in context. Canadian Journal of Science, Mathematics and Technology Education, 18(2), 177-186. https://doi.org/10.1007/ s42330-018-0009-0.

Jao, L., Sahmbi, G., \& Huang, Y. S. (2020). Professional growth through reflection and an approximation of practice: Experiences of preservice teachers as teaching assistants in a secondary mathematics teaching methods course. The Teacher Educator, 55(1), 47-65. https://doi.org/10.1080/08878730. 2019.1637986 .

Jordan, S., \& Kapoor, D. (2016). Re-politicizing participatory action research: Unmasking neoliberalism and the illusions of participation. Educational Action Research, 24(1), 134-149. https://doi.org/10. 1080/09650792.2015.1105145.

Kamat, S. (2004). The privatization of public interest: Theorizing NGO discourse in a neoliberal era. Review of International Political Economy, 11(1), 155-176. https://doi.org/10.1080/0969229042 000179794.

LaDousa, C., \& Baldrige, A. (2017). Agency and the GED: Personae and artifacts in the figured world of a literacy welcome center. Ethos, 45(1), 116-138. https://doi.org/10.1111/etho.12157.

Masucci, M., Pearsall, H., \& Wiig, A. (2020). The smart city conundrum for social justice: Youth perspectives on digital technologies and urban transformations. Annals of the American Association of Geographers, 110(2), 476-484. https://doi.org/10.1080/24694452.2019.1617101.

McCrystal, L., Graham, K.A., \& Terruso, J. (2020). Coronavirus impact: Philly schools face $\$ 1$ billion hole over 5 years as Kenney administration asks departments to cut budgets by $20 \%$. The Philadelphia Inquirer, 23 April [online article]. Retrieved 14 June 2020 from https://www.inquirer.com/ news/budget-philadelphia-school-district-city-cuts-staff-servcies-kenney-20200423.html.

Mulhere, K. (2015). GED Drop. Inside Higher Ed, 20 January [online article]. Retrieved 14 June 2020 from https://www.insidehighered.com/news/2015/01/20/ged-numbers-down-amid-time-transitionhigh-school-equivalency-exams.

Murphy, D.C. (2017). E3 centers give students another shot at dreams. The Notebook, 9 June [online article]. Retrieved 14 June 2020 from https://thenotebook.org/articles/2017/06/09/e3-centers-give-stude nts-another-shot-at-dreams.

Muhl, C.J. (2001). The employment-at-will doctrine: Three major exceptions. Monthly Labor Review, 124(1), 3-11. Retrieved 18 February 2021 from https://www.bls.gov/opub/mlr/2001/01/art1full.pdf.

Nicola, M., Alsafi, Z., Sohrabi, C., Kerwan, A., Al-Jabir, A., Iosifidis, C., Agha, M. \& Agha, R. (2020). The socio-economic implications of the coronavirus pandemic (COVID-19): A review. International Journal of Surgery, 78, 185-193. https://doi.org/10.1016/j.ijsu.2020.04.018.

Peters, M.A., \& Wals, A E. (2016). Transgressive learning in times of global systemic dysfunction: Interview with Arjen Wals. Open Review of Educational Research, 3(1), 179-189. https://doi.org/10. 1080/23265507.2016.1217166.

Pew Research Center (2018). Philadelphia's poor: Experiences from below the poverty line. A report. Washington, DC: The Pew Charitable Trusts. Retrieved 14 June 2020 from https:/www.pewtrusts. org/-/media/assets/2018/09/phillypovertyreport2018.pdf.

Pinder, H. (2020). As COVID-19 deepens the digital divide, a call to move beyond simply providing access. Technically, 27 April [online article]. Retrieved 14 June 2020 from https://technical.ly/ philly/2020/04/27/as-covid-19-deepens-the-digital-divide-a-call-to-move-beyond-simply-provi ding-access/.

Prins, E., Clymer, C., Foreman, S.S., Loa, M., Needle, M., Raymond, B., Toco, B.W. \& Ziskind, A. (2018). Career pathways programming for adult learners in Chicago, Houston, and Miami: Final report. University Park, PA: Institute for the Study of Adult Literacy.

Prins, E. (2017). Conclusion. New Directions for Adult and Continuing Education, 155, 95-103. https:// doi.org/10.1002/ace.20244. 
Prins, E. (2009). Examining interpersonal dynamics among adult learners through the lens of place. International Journal of Lifelong Education, 28(1), 91-106. https://doi.org/10.1080/0260137080 2571253.

Prins, E., Toso, B.W., \& Schafft, K.A. (2009). "It feels like a little family to me": Social interaction and support among women in adult education and family literacy. Adult Education Quarterly, 59(4), 335-352. https://doi.org/10.1177/0741713609331705.

PYN (Philadelphia Youth Network) (2020). Investors: Key investors that have supported PYN-managed initiatives, programs and systems-building efforts during fiscal years 2014 to present [dedicated webpage]. Philadelphia, PA: Philadelphia Youth Network, Inc. Retrieved 10 November 2020 from https://www.pyninc.org/investors.

Rachal, J.R., \& Bingham, M.J. (2004). The adolescentizing of the GED. Adult Basic Education, 14(1), 32-44.

Risager, B.S. (2016). Neoliberalism is a political project: An interview with David Harvey. Jacobin, 23 July [online article]. Retrieved 10 November 2020 from https://www.jacobinmag.com/2016/07/ david-harvey-neoliberalism-capitalism-labor-crisis-resistance

Ritchie, G. (2017). "Youth" as theory, method, and praxis. In S. Carpenter \& S. Mojab (Eds), Youth as/in crisis (pp. 11-26). Rotterdam/Boston/Taipei: Sense Publishers.

Ronai, C.R. (1992). The reflexive self through narrative: A night in the life of an erotic dancer/researcher. In C. Ellis \& M. G. Flaherty (Eds), Investigating subjectivity: Research on lived experience (pp. 10-124). Newbury Park, CA: Sage.

Ruglis, J. (2011). Mapping the biopolitics of school dropout and youth resistance. International Journal of Qualitative Studies in Education, 24(5), 627-637. https://doi.org/10.1080/09518398.2011. 600268.

Schwartz, J. (2014). High school equivalency as counter-space. New Directions for Adult and Continuing Education, 144, 37-47. https://doi.org/10.1002/ace.20112.

Selwyn, N., \& Jandrić P. (2020). Postdigital living in the age of covid-19: Unsettling what we see as possible. Postdigital Science and Education, 2(3), 989-1005https://doi.org/10.1007/ s42438-020-00166-9.

Shange, S. (2019). Black girl ordinary: Flesh, carcerality, and the refusal of ethnography. Transforming Anthropology, 27(1), 3-21. https://doi.org/10.1111/traa.12143.

Simon, S. (2013). Cash cow seen in revamped GED. Politico, 30 December [online article]. Retrieved 14 June 2020 from https://www.politico.com/story/2013/12/testing-companies-see-cash-cow-in-revam ped-ged-101602.

Simon, S. (2015). No profit left behind. Politico, 10 February [online article]. Retrieved 14 June 2020 from https://www.politico.com/story/2015/02/pearson-education-115026

Sukarieh, M. \& Tannock, S. (2016). On the political economy of youth: A comment. Journal of Youth Studies, 19(9), 1281-1289. https://doi.org/10.1080/13676261.2016.1206869.

Taber, N. (2010). Institutional ethnography, autoethnography, and narrative: An argument for incorporating multiple methodologies. Qualitative research, 10(1), 5-25. https://doi.org/10.1177/1468794109 348680 .

Tuck, E. (2011). Humiliating ironies and dangerous dignities: A dialectic of school pushout. International Journal of Qualitative Studies in Education, 24(7), 817-827. https://doi.org/10.1080/09518 398.2011 .632785 .

Tuck, E. (2012). Urban youth and school pushout: Gateways, get-aways, and the GED. Critical Youth Studies series. New York: Routledge.

Tuck, E., \& Yang, K.W. (2011). Youth resistance revisited: New theories of youth negotiations of educational injustices. International Journal of Qualitative Studies in Education, 24(5), 521-530. https:// doi.org/10.1080/09518398.2011.600274.

UNESCO (United Nations Educational, Scientific and Cultural Organization) (2004). Empowering youth through national policies: UNESCO's contribution. Paris: UNESCO. Retrieved 18 February 2021 from https://unesdoc.unesco.org/ark:/48223/pf0000134502.

Vargas, C. (2020). Most looters are young Philadelphians not associated with the protests, DA says. National Broadcasting Company, 1 June [online news item with video]. Retrieved 14 June 2020 from https://www.nbcphiladelphia.com/news/local/most-looters-and-vandals-appear-to-be-youngphiladelphians-not-associated-with-the-protests-da-says/2416086/.

Wacquant, L. (2009). Punishing the poor: The neoliberal government of social insecurity. Durham, NC: Duke University Press. 
WHO (World Health Organization) (2020). WHO Director-General's opening remarks at the media briefing on COVID-19 - 11 March 2020. WHO, 11 March [webnews]. Geneva: World Health Organization. Retrieved 2 February 2021 from https://www.who.int/director-general/speeches/detail/whodirector-general-s-opening-remarks-at-the-media-briefing-on-covid-19---11-march-2020.

Zinth, J. (2015). GED, HiSET and TASC: A comparison of high school equivalency assessments. ECS Education Trends series, July. Denver, CO: Education Commission of the States. Retrieved 10 October 2020 from https://files.eric.ed.gov/fulltext/ED558072.pdf.

Publisher's Note Springer Nature remains neutral with regard to jurisdictional claims in published maps and institutional affiliations.

Isaiah Zukowski is a PhD student in Adult Education and Lifelong Learning at Pennsylvania State University in the United States. Prior to teaching high school equivalency (HSE) in Philadelphia, Isaiah worked as an English as a Second Language (ESL) programme instructor in Baltimore County, Maryland, as a Fulbright English Teaching Assistant in Tunja, Colombia, and as the Supportive Services Coordinator at Bradbury-Sullivan LGBT Community Center in Allentown, Pennsylvania.

Zachary Parker is a PhD candidate in Educational Studies in the Department of Integrated Studies in Education (DISE) at McGill University in Canada. He has been an instructor of high school equivalency (HSE) since 2015 in Pennsylvania. Prior to this role, he has worked in public schools or higher education since 2001 in the US, Malawi, Liberia and Canada.

Daisy Shetterly received her BA in Sociology from Bryn Mawr College. She began teaching high school equivalency in 2014 at the Minmahaw Higher Education Program in Mae Sot, Thailand. She has been teaching at Congreso de Latinos Unidos since 2018.

Kimberly Valle is a Master's of Public Policy and Administration student at Rutgers University-Camden in the United States. She has been teaching young adults in the United States and internationally since 2016 through her role as a Peace Corps volunteer in Morocco and as an education youth specialist in El Paso, Texas.

\section{Authors and Affiliations}

\section{Isaiah Zukowski ${ }^{1}\left[\right.$ Zachary Parker $^{2} \cdot$ Daisy Shetterly $^{3} \cdot$ Kimberly Valle $^{4}$}

Zachary Parker

zachary.parker@mail.mcgill.ca

Daisy Shetterly

daisyshetterly@gmail.com

Kimberly Valle

kimvdelrio@gmail.com

1 Lifelong Learning and Adult Education Program, College of Education, Pennsylvania State University, University Park, PA, USA

2 Department of Integrated Studies in Education, Faculty of Education, McGill University, Montreal, QC, Canada

3 Congreso de Latinos Unidos, Philadelphia, PA, USA

4 Rutgers University-Camden, Camden, NJ, USA 